\title{
DOME FORM TYPOLOGY OF ISLAMIC ARCHITECTURE IN PERSIA
}

Received August 22nd 2017 | Accepted October 9th 2017| Available online December 15th 2017| | DOI: 10.18860/jia.v4i4.4374|

\section{Wasilah}

Department of Architecture

Faculty of Science and Technology

State Islamic University Alauddin

Makassar, Indonesia

wasilah@uin-alauddin.ac.id

\begin{abstract}
Aim of this research is to describe the dome form typology of Islamic Architecture in Persia area. This research applies descriptive qualitative method with physiognomy concept approach as a method in interpreting architecture object. This research methods also identify a particular physical object based on the style of Persian Area (Iran and Middle Asia) which correlated with the origin of dome form. The result explained that the dome typology in Islamic Architecture of Persia style has six types. Most of the types are the development gateway curvature (iwan) as the characteristic feature of Persian architecture.
\end{abstract}

KEYWORDS:

Typology; dome; Islamic architecture; Persia

\section{INTRODUCTION}

Islamic architecture significantly is influenced by tradition and culture. Islamic architecture is identical with "architecture creation of Islamic culture", not just the actualization form, but also in essential values from morality/character spirit and wisdom [1]. One of the element in Islamic architecture is the dome roof as a popular symbol and easily identified as Islamic building, especially for the mosque.

The dome is the architecture heritage since Roman period, then adopted by the buildings in the Byzantine period. Because of the aesthetic and monumental appearance, most of the churches architecture applied this in Early Christianity era. In addition, the dome construction possibly has a wide span structure without interrupted by the column at the center of the room, so the harmony in salăt aljamā'at become solid. The hypostyle mosque architecture in the age of Ottoman in Turkey since the XII century with column or sometime hundreds column inside the praying room are not applicable anymore. Dome constructions are preferred because of its advantages.

Mosques with dome roof found easily in remote area and grand mosque that located in the center of the city of Islamic area development. One of nine globally Islamic architecture development according to the place and the history is Persia, that consists of Iran and Central Asia. Likewise with another regions, Persian architecture considerably has dome building characteristic, such as in mosque, palace, school (Islamic school), and tomb.

Based on physiognomy concept approach, dome form typology in Persian Islamic architecture have identified in accordance with the characteristics or feature of architecture ornamentation to know how the development of dome typologies in Persian architecture.

\section{ARC HITECTURE TYPOLOGY}

Typology is the analysis of type [2]. The word of type is from typos (Greeks). The meaning is impression, image, or figure of something. Generally, type is functioned as explanation to the entire form, structure, or character of form or particular object. According to the object of the building, the typology divided into three parts, which are site, form, and organization of the part of the building. In architecture, typology is emphasized on variation of style ordering system variation that related on roof construction, form, and opening pattern of room formation, ornamental and the overall appearance of the building. The typology mostly refers to the concept and consistency that help the society easily identify the parts of the architecture.

Typology correlated directly with the architectural object, a study that tries to track the origin or the beginning of the architectural objects formation. The concept of physiognomy is an interpretation method on architectural object by identify the particular physical object. The concept will describe a certain image. In this context, typology is also considered as categorizing activity based on the style, because every object has specific types in accordance with the function and society habit in application of the object. The style refers to more specific item, which related on characteristic or feature 
architecture ornamentation in certain time, period, region, or person.

As a result, typology is a concept or action of thinking in frame of classification and categorizing the architecture object based on the similarities of basic forms, basic characteristic, style, symbolism in the existing social context and the origin and the development process of architecture form. Therefore, typology is a classification to categorize the building according to well-defined type.

\section{ISLAMIC ARCHITECTURE}

Islamic architecture is perceived as architecture types that express Islamic way of life. The relation between architecture and Islam manifests by aesthetic creativity and technique from the idea of religion. However, atmosphere of Islam is also applied in the creation of architecture as secularism function. Consequently, Islamic architecture is all architecture works, either function as spirituality or secularity from Islamic lands. Islamic architecture is not the mosque building only but also includes the buildings of Islamic culture manifestation, such as tomb, palace, market, bath house, lodging, Islamic school, residence, fortress, and etc.

Nu'man [1] more emphasizes the Islamic architecture is identical with "architecture creation of Islamic culture", not as the form actualization only but also in essential values from morality/character spirit and wisdom. Therefore, Islamic architecture is an architecture that full of content and expression of the local value of the Islam. Islamic architecture is the result of Islamic culture that correlated with essential values of morality/characteristic spirit of Islam as religion, but the symbolism certainly presenting Islamic nuance.

Global architecture development categorization based on the location and the history are divided into nine regions, Arab and nearby areas, Spain and North Africa, Iran and Central Asia, Anatolia, India, Sub-Saharan West Africa, East Africa, China and Southeast Asia [3]. Discussion on this paper focus on two regions, Iran and Central Asia include Anatolia which have relation with the origins of dome form found.

According to the figure 1, Persia consist of Iran and Central Asia. Geographically, Persia is border area between Europe and Asia, spread out east-west from the east of China, including Badakhshan Mountain Range and Central Afghanistan to the Indian Ocean, large desert in east of Iran and Transoxiana, west and central plateau of Iran and Caspian Sea.

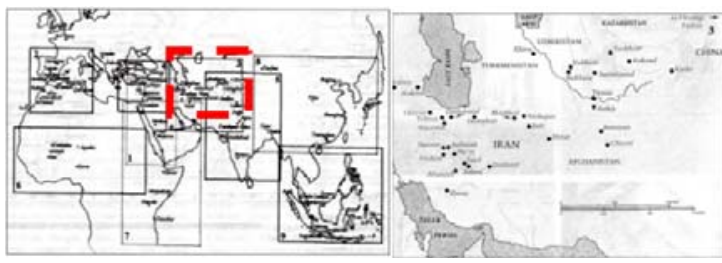

Figure 1. Muslim World Map and Persian Map [3]
DOME

Dome is arch or hemispherical arched roof dome (cupola) [4]. There are "plate dome" (because the top is low with wider base) and "onion dome" (because similar with onion form). Generally the dome is positioned in the highest place on the top of the building (as the roof), straight on the framing with pendentive.

The advantage of dome construction may form a wide span without the column in the middle, because the structure has form a half section half a sphere, parabola and others may radiates equal force to all direction. The dome depends on the thickness, directly proportional with the span (thicker, wider span) In the modern construction, the ferrocement may construct the dome more easily and efficiently. In addition, the dome has specific form, beautiful and elegant [3].

\section{THE HISTORY OF DOME}

Before the Islam enters to Persia, Sassanid architecture is dominant with arch dome feature as a building roofing, terraced may even exist [5]. Additionally, Parthian City excavation in Nyssa found dome construction 17 meter in diameter, built about in first century [6]. The painting found in 8th century in Panjikent, Soghdian is illustrated in the picture of the wooden dome structure that covered by the tent (Figure 2).

In addition, more dome exists in the Persian architecture of Mohammedan and Byzantine. In some districts, man built the dome with the stone, brick or clay, because of wood unavailability as in Assyria. In some cases, some of the dome form or tunnel thought as a protection place.

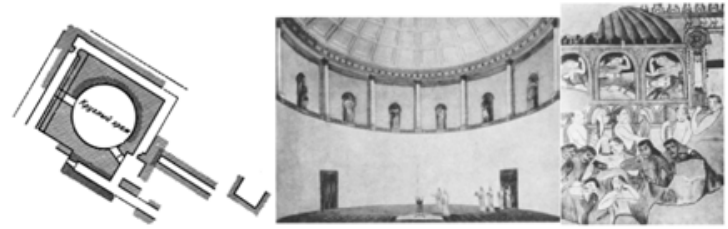

Figure 2. Circular hall reconstruction, Nyssa and Panjikent painting [6]

Roman architecture (300 BC-364 AD) has begun round and arch form, developed into three dimension to form a dome [7]. Pantheon Rome has the biggest temple in its age, built by Agrippa in $27 \mathrm{BC}$ then reconstruction by Hadrian (117-125 AD), and became the church in VII century (Figure 3 ). The main hall is rotunda $43.43 \mathrm{~m}$ in diameter, roofing by dome $40 \mathrm{~m}$ in diameter. There is a hole covered by glass at the top of the dome to provide the sun light. The interior circle part forms the blocks. The block become smaller into the top that expose by the line, become beautiful rectangular decoration element. The intrados dome decorated with molding formed circular lines.

Uniquely, the cella diameter is equal to the building height. A sphere will create when creating a straight line in cross-section through central point of interior to the top of the dome. Viollet-le-Duc in his paper praise Pantheon dome as "This majestic cupola 
is the widest, the most beautiful, the best constructed, and most stable of all the great domes of the world".
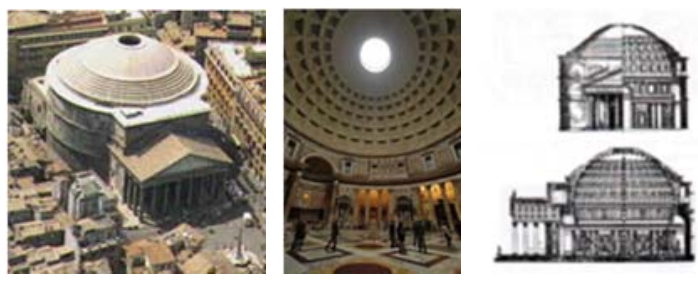

Figure 3. Pantheon, Rome [8]

Constantine the Great expands the Rome ruler area and moves the capital city to Constantinople or the New Rome in 330, presently the region covered the Turkey area. In the age of Byzantine (330-1453 AD), the dome is most feature as polygonal roof or square which supported by circular on the dome base (pendentive construction). To complete the capital city of the Empire, a greatest church built in Constantinople named as Saint Sophia (Hagia Sophia) which mean as "devine wisdom". The architect of the church is Anthemius from Tralles and Isodorus from Militus. The S. Sophia church built in 532-537, representation of Byzantine greatest, luxurious, beautiful and monumental church architecture. The central room is square $(32.60 \mathrm{mz})$, the dome diameter is $32.60 \mathrm{~m}$, the top of the dome is $54.80 \mathrm{~m}$ from the ground, and form pendentive in every corner. There are 40 windows around around the dome base as a solution the interior becoming dark (Figure 4).

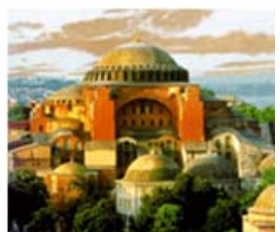

Figure 4. Saint Sophia (Hagia Sophia) Church in Constantinopel [7]
Then the dome becomes the characteristic of Byzantine architecture. Most of the church built by the dome with various form, such as small domes series or compound, dome wood frame which function only as support and ceiling and compound "false dome". In addition, there is modification in onion dome with more concave, bloated underneath and pointed to the top. Moreover, The Saint Basil Church the Blessed in Kremlin Red Square Moscow applied a little Byzantine aspect and modified with local form that is the onion dome, all abutment wall and drum are colorful and decorated with lines likes molding (Figure 5).
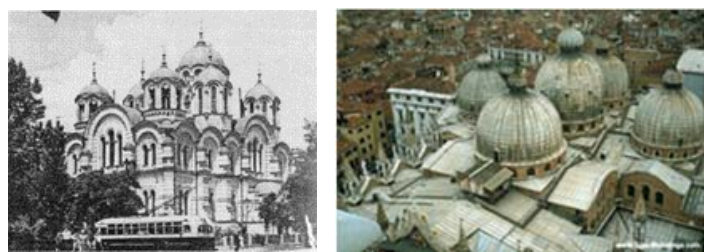

Figure 5. Modification of Byzantine dome in Hagia Sophia Church in Kiev, Saint Mark's Basilica in Venice [3]
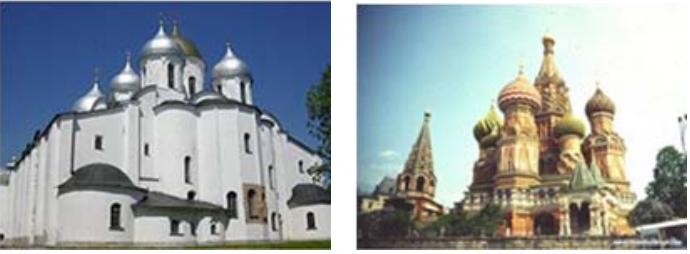

Figure 6. Saint Sophia Church in Novgorod and Saint Basil Cathedral in Kremlin, Moscow [3]

\section{METHODS}

This research applied a descriptive qualitative method with physiognomy concept approach. This method is interpreting architecture object by identifying a particular physical object based on the style of Persian area (Iran and Middle Asia) which correlated with the origin of dome form.

\section{RESULTAND DISC USSION}

Byzantine period architecture (330-1453) coinciding with Early Christianity period and Early Islamic in VII century, then dome application is dominant in both architecture. Because of the possibility on wide span without any disruption by column in the center of the room, beautiful form, and monumental appearance, creates a harmony in salāt aljamā'at [3].

There are many mosques where the roof is identical with onion dome in Persian area as a development form and modification of Persian local element. The characteristic feature of Persian architecture in the arched gate construction or iwan is entrance/gateway with arched roof form that closed the three part of gateway body wall, but opened in the front wall. During the development, iwan had been modified into various appearance, such as top pointed, sharp or curve pointed to top (Figure 6). In addition, the mosque roof and the tomb developed into conical dome form.

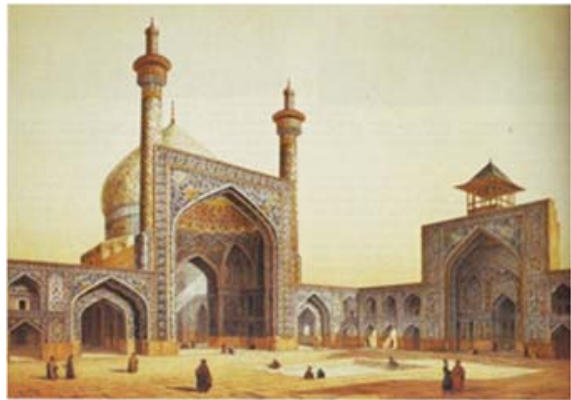

Figure 7. Persian (iwan) gateway curvature [9]

\section{CONICALDOME}

The result of iwan modification in mosque roof and the tomb called as conical dome with dome section less horizontal, pointed-arched form or archedfracture, top pointed with circular section. The dome outrados is laminated by blue ceramic with intricategeometric or floral-arabesque motif. In addition, the vault or dome interior (intrados) decorated with arabesques, intricate, muqarnas, calligraphy and combination of exposed brick structure that formed 
geometrical pattern as the characteristic features of Persia. In addition, rectangular base construction modified into octagon or polygon that almost similar with star sides, became smaller to the top. As result, the base area is bigger. New planes as form residual transitions utilize as window holes with as the residual of form transition utilize as window opening arched breakpoint limit that directly lighting the underneath room. Example of conical dome application is in Shah Mosque and Sheikh Lotfollah Mosque in the Complex of Maidan (masque and palace) of Isfahan, Iran (Figure 7).

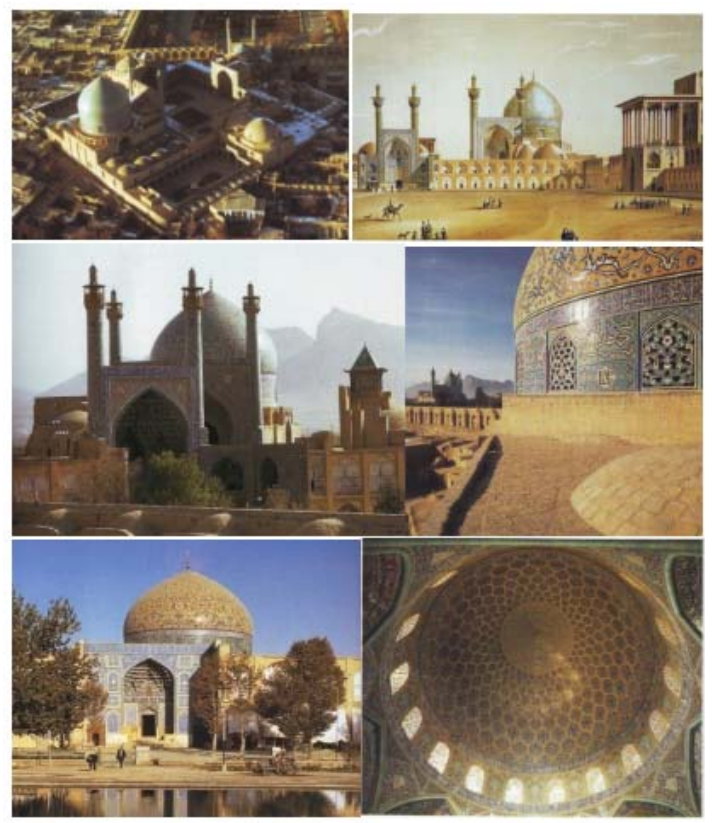

Figure 8. The Complex of Maidan (mosque and palace), Shah Mosque (kingdom) and Sheikh Lotfollah Mosque in Isfahan, Iran [9]

\section{THE CONICALDOME IN HIGH DRUM}

This dome type is similar with the conical dome, but different on the footing with high drum. Decoration of drum dominantly by calligraphy framed with arabesque and intricate ornament. The dome overlaid by blue-shining ceramic. The example of building with this dome is Mir-I-Arab Madrasa in Bukhara (Figure 8)

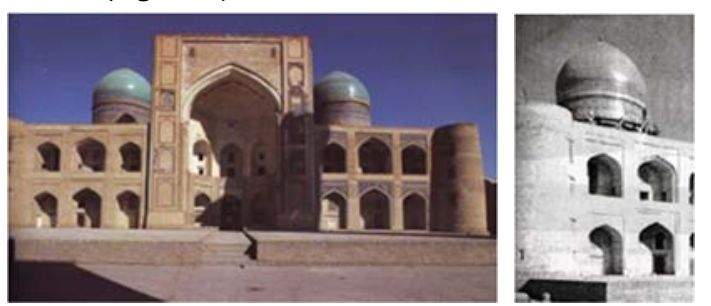

Figure 9. Mir-I-Arab Madrasa in Bukhara [9]

\section{BULBOUS DOME}

The bulbous dome is similar with onion dome, top pointed, bulbous in the central part and become smaller to the bottom. There is a high-cylinder drum under the circular dome to neutralize a low interior. The wall laminates by ceramic and colorful mosaic and all part of the dome overlaid by excessively blue ceramic. According to the figure 9, this dome types applied in the building of Bibi-Khanum Mosque in Samarkand.

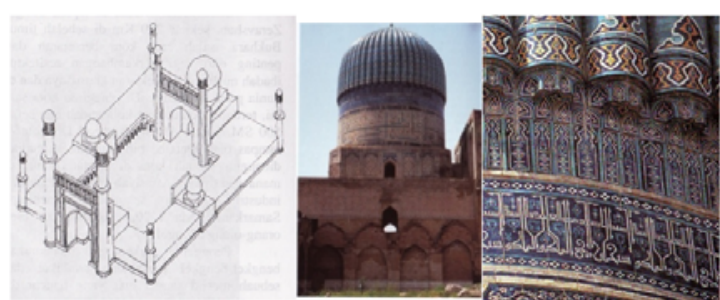

Figure 10. Bibi-Khanum Mosque in Samarkand [3]

\section{MELON-RIBS DOME}

There is melon-ribs dome model in the Timurid Empire. The characteristic of melon-ribs dome laid on high drum, the intrados decorated by muqarnas, the extrados part is not flat form horizontal line as independent ornament. In addition, melon-ribs dome is decorated by intricate and arabesque geometrical pattern and overlaid by ceramic, colorful, or blue shining mosaic. The dome layers consist of external and internal wall or like a ceiling. These two laminates concentrate underneath and create a drum ring. The ceiling is not laminate only but the ceiling is part of structur. There is column at the top where the piles joint external lamination of the dome. The extrados is more bulbous than the intrados, because the extrados is high and far visible and the intrados is always deep and closer. As a result, there is no convex impression difference, harmony, and compatible. According to the figure 10, the example of this dome type is in Gur-I Mir mausoleum building and complex of Ulugh Beg mosque-madrasa, Tilla Kari and Sher-Dor in Samarkand.
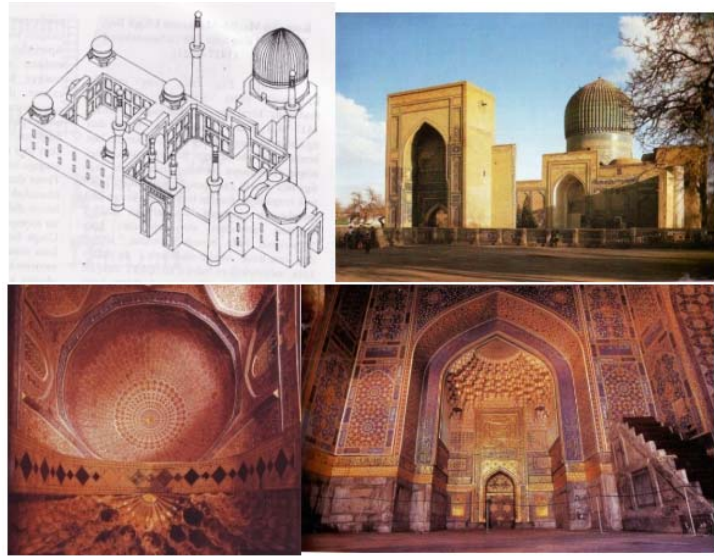

Figure 11. ShirDor Mosque in Samarkand [9]

\section{THE RIBBED DOME}

The form of the dome lays on the drum that is relatively high, decorated by ceramic in calligraphy pattern, intricate and arabesque. There are windows as number as footing side in the section area for natural lighting. There is ceiling inside the dome. The high of ceiling is less than a half of dome height, known as double dome with muqarnas decoration. According to the figure 11, this type of dome applied in MosqueThomb Abu Nasr Parsa, Balkh. 

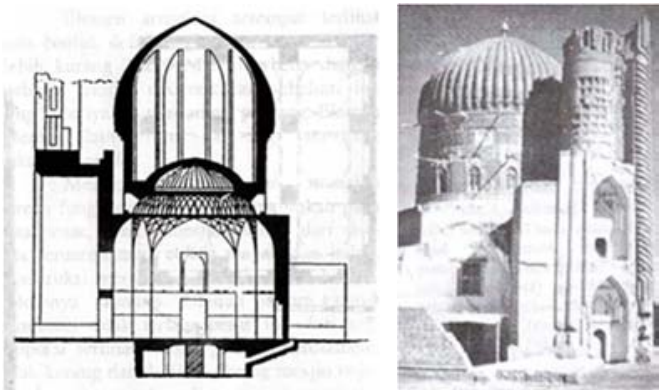

Figure 12. Mosque-Thomb Abu Nasr Parsa, Balkh [3]

\section{MEION-RIBBED-DOME}

The melon-ribbed-dome is a combination of ribbed dome and melon shape dome with bubbly profile form that consist of small curvatures. The middle part of melon-ribbed-dome is bulbous and bigger than the bottom like a melon. The footing of the main dome is octagon floor, laid on the footing underneath, with square cross section is equal to floor plan. The dome is decorated with dark blue, blue light, maize and white color ceramics. The interior footing side is decorated with calligraphy and the introdus part is decorated with big-size muqarnas. The example of this dome is in the figure 12; Khoja Ahmed Yasavi mosque-mausoleum in Turkestan.
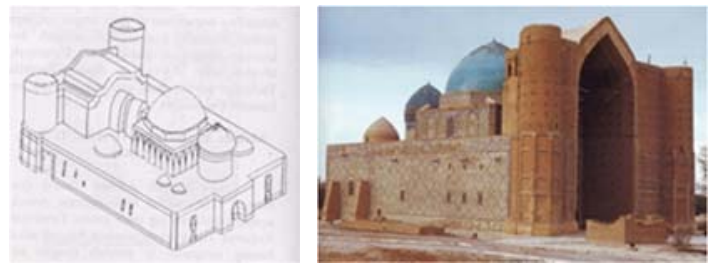

Figure 12. Khoja Ahmed Yasavi mosque-mausoleum in Turkestan City [9]

\section{CONCLUSION}

The result of this research explained that the dome in the Persian Islamic architecture development is from gateway curvature (iwan). Characteristic feature of Persian architecture is similar with onion dome in Byzantine architecture. There are six types dome form typology in Persian Islamic architecture, that are conical dome, conical dome with high drum, bulbous dome, melon-ribs dome, ribbed dome, and melon-ribbed-dome.

The dome exterior is laminated by ceramic, dominantly with blue color intricate-geometric pattern or floral-arabesque. In addition, the vault or dome interior (intrados) is decorated with arabesque, intricate, muqarnas, calligraphy and combination of exposed brick structure that formed geometrical pattern as the characteristic features of Persia. Moreover, base construction is dominant with octagon and polygon almost identical with the star corners, became smaller to the top. As a result, the base area is bigger and new section of the form transition utilize as the hole of the window with arch to enter a natural lighting to the room directly.

\section{REERENCES}

[1] F. Nu'man, "Arsitektur Islami, Bukan Sekedar Bentuk," Majalah Techno Konstruksi, vol. 5, no. 1, Jakarta, Sep-2008.

[2] M. S. B. Iskandar, "Tradisional dan Modernitas Tipologi Arsitektur Masjid (Traditional and Modernity of Mosque Architecture Typology)," Jurnal Dimensi Teknik Arsitektur, vol. 32, no. 2, 2004.

[3] Y. Sumalyo, Arsitektur Mesjid dan Monumen Sejarah Muslim (Mosque Architecture and History Monument of Muslim). Yogyakarta: Gajahmada University Press, 2006.

[4] Department of National Education of Indonesia, Kamus Besar Bahasa Indonesia Edisi Ketiga (Great Dictionary of the Indonesian Language Third Edition). Jakarta: Balai Pustaka, 2002.

[5] A. Rochym, Sejarah Arsitektur Islam, SebuahTinjauan (Islamic architecture History, A Review). Bandung: Angkasa, 1983.

[6] O. Grabar, "The Islamic Dome, Some Consideration," J. Soc. Archit. Hist., vol. 22, no. 4, 1963.

[7] Y. Sumalyo, Arsitektur Klasik Eropa (Classical Architecture of Europe). Yogyakarta: Gajahmada University Press, 2003.

[8] “No Title." [Online]. Available: www.greatbuildings.com. [Accessed: 20-Nov2017].

[9] Hattstein and Delius, Islam Art and Architecture. Italy: Könemann, 2004. 